\title{
Value Addition of Grains using Solid State Fermentation
}

\author{
V Eyarkai Nambi*1, V Chandrasekar ${ }^{2}$ and S Karthikeyan ${ }^{3}$ \\ ${ }^{1}$ Division of Transfer of Technology, ICAR-CIPHET, India \\ ${ }^{2}$ Division Agricultural Structures and Environment Control, ICAR-CIPHET, India \\ ${ }^{3}$ Department of Bioenergy, Tamilnadu Agricultural University, India
}

Submission: September 12, 2017; Published: October 26, 2017

*Corresponding author: V Eyarkai Nambi, Division of Transfer of Technology, ICAR-CIPHET, Ludhiana, India, Tel: 91-422-6611272, Fax: 91-04226611455; Email: eyarkainambi@gmail.com

\section{Abstract}

Solid state fermentation (SSF) is a bioconversion process by microorganism and enzymes. It effectively depolymerizes the cellulose, ligno cellulose present in the agricultural produces, cereals and biomas. It also enriches protein, colour, antioxidant activity, modification of functional properties of cereals. Solid state fermentation provides wide range of application in food and bio processing industries. This article focuses on the use of SSF for value addition of cereals along with the factors affecting the solid state fermentation process.

Keywords: Solid state fermentation; Pseudo cereal; Value addition; Parameters.

\section{Introduction}

Grains are used in regular diet of the people. In Asia and Africa, grains such as cereals and legumes based foods are common. Grains are the source of carbohydrate and protein to the humans and animals. Grains contain a wide range of chemical components with radical scaving activity of antioxidant property. Grains provide significant quantities of energy, protein and selected minerals in the animal and human diet. Grains are rich in phenolic acids and saponins [1]. The antioxidant properties of phenolic compounds present in the grains are associated with the health benefits attributed to those grains and the products derived from them [2]. Legumes (poor man's meat) play an important role in human nutrition since they are rich sources of protein, calories, minerals and vitamins and therefore can be good supplements [3]. Chemical composition and bioavailability of nutrients vary between species and varieties of grains and may be affected by the forms of processing as feed and food [1]. It may also improve digestibility and nutritional value of food and feed. Previous studies have shown that microorganisms start to modify plant constituents during fermentation [4]. Many biochemical changes occur during fermentation, leading to altered ratio of nutritive and anti-nutritive components of plants, which affect product properties such as bioactivity and digestibility [5]. Solid state fermentation (SSF) is an alternative technology for processing of various gains to improve their nutritional quality and to obtain edible products with palatable sensorial characteristics. More-recent applications of SSF include the protein enrichment of agro-industrial residues for the production of enzymes, organic acids, spore production and other fungal metabolites [6].

\section{Solid State Fermentation}

Solid state fermentation (SSF) is a fermentation process carried out on a natural state of solid medium with a low moisture content about $0.40-0.90 \mathrm{wb}[7,8]$ and carried out by a limited number of microorganisms, mainly yeasts and fungi, although some bacteria have also been used [9]. In SSF process, the solid substrate not only supplies the nutrients to the culture but also serves as an anchorage for the microbial cells [10]. In SSF, the aqueous film of liquid phase surrounds the substrate particles and gas phase filled the space between particles. Microbial growth and metabolism occur in an aqueous phase due to solutes and/or substrates diffusing through aqueous phase.

Solid state fermentation technology isused for food production, enzymes [11], animal feeds [12]. Advantage of SSF is the production of high concentration of microorganisms with low microbial contamination due to low humidity of 
medium [13]. SSF receives more attention from the industry for producing enzymes due to its economic and engineering advantages [14]; high productyields and simplified downstream processing [15]. The most important advantage of SSF is improved product recovery, reduced energy requirements and simplicity of the equipment used [16]; simpler technique and lower cost [10] as compared with submerged fermentation. The amount of specific enzymes produced through SSF is greater than (Submerged fermentation) SmF [17]. Many bacteria and fungi have been utilized for production of industrially important products by SSF [18].

\section{Procedure for solid state fermentation}

The entire process flow chart of solid state fermentation of grains is given in the Figure 1.

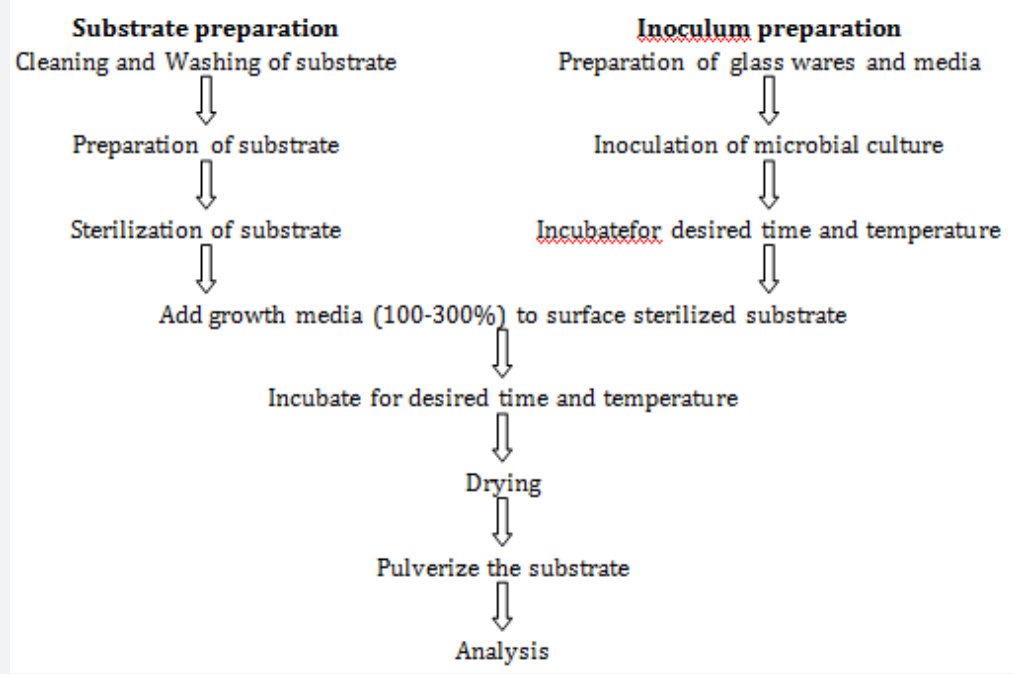

Figure 1: Flow chart of fermentation process

\section{Substrate Preparation}

Substrate is cleaned and washed to remove foreign matters. Precondition the substrate suitable for solid state fermentation by soaking or drying.

Figure.1: Flow chart of fermentation process

\section{Culture Preparation}

The suitable microbial culture is grown and maintained on media. Growth media is prepared with suitable minerals like potassium di-hyrdogen phosphate (KH2PO4), Magnesium dihyrdogen sulphate (MgSO4), soluble starch and trace amount of Iron (II) Sulfate Heptahydrate (FeSO4.7H20)). The growth media were inoculated with overnight grown microbialculture and incubated.

\section{Solid state fermentation}

Take the prepared substrate in a fermentation container. Adjust the required initial $\mathrm{pH}$ by adding $1 \mathrm{~N} \mathrm{NaOH}$ or $1 \mathrm{~N}$ HCL. Then add the growth media to substrate and incubated at specific temperature for desired time. After incubation, substrate is dried to reduce the moisture content less than 10 percent, d.b. and pulverized for further use.

\section{Application of solid state fermentation}

\section{Enzyme production}

Cereals enzymes play an important role by converting carbohydrates, proteins, phenolic compounds and lipids during metabolism. These cereal enzymes convert the polysaccharides to fermentable monosaccharides. The release of maltose and glucose by cereal enzymes during fermentation determines the exopolysaccharide yield in sourdough fermentations [19]. The alpha amylase activity of the finger millet was increased from 90 to $158 \mathrm{U} / \mathrm{mg}$ by solid state fermentation using Aspergillus oryzae [20]. $\alpha$-amylase activity of the substrate combination of Oryza sativa and Lablab purpureus seeds and flour was higher than non fermented seeds and flour [2]. Thermostable amylases was produced from wheat bran, rice-bran, corn bran and combination of two brans using Bacillus sp by solid state fermentation [21].Lipase was produced from ground nut and barley bran using SSF by the yeast Y. lipolytica [22]. Enzymes produced from the wheat bran by SSF have a broad $\mathrm{pH}$ range of activity, moderate thermo- stability, and appropriate temperature profile. It is suitable for using as as an additive for starch, biofuel and detergent industries [23]. Fungal amaylase produced by solid state fermentation increased the level of 
fermentable sugars in the dough and it enhances the quality of sour dough $[24,25]$. The amylase degrades the substantial amount of starch in rye flour during baking [26]. Amylase and protease are mainly produced during growth phase of Aspergillus oryzae on roasted cracked soya beans and wheat [27]. Better invertase production, biomass growth, enzyme yield in solid-state was due to a better mould growth observed by [28]. Peptidase was produced using Aspergillumsoryzae from wheat bran in Koji making [29]. A maximum xylanase activity of $757.4 \mathrm{IU} / \mathrm{g}$ and a cellulase activity of $3.2 \mathrm{IU} / \mathrm{g}$ were achieved by SSF of soybean cotyledon fiber using T. reesei, P. chrysosporium and A. oryzae [30]. Solid state fermentation was used for producing highest xylanase activity of 399.2IU/g from distiller's dried grains with soluble (DDGS) [30].

\section{Nutrition enrichment}

All grains are not nutritionally balanced due to of its antinutritional factors. Therefore the nutrition enrichment grain gains more market value. Enrichment is state the addition or improves one or more vitamins or minerals or protein to grains. Solid state fermentation enriches the nutrient based on the enzymes secreted during fermentation. Mixed Solid state fermentation using Rhizopus oligosporus on dehulled cereal viz Seteria italica and legume viz.Cicer arietinum (Bengal gram or chola or chick pea) increased the B vitamins (thiamine, niacin and vitamin B6) (Sultanaet al., 2011). Fermentation increased the fibrous residue in cassava flour and also increased the cooking quality (George, 1984). SSF increased protein content of common bean flour of $21.7 \%$ along with six of the essential amino acids which is including total sulfur (Met + Cys) and it also decreased the phytic acid of 58.3\%(Reyes-Bastidas et al., 2010) [31]. Protein content doubled in fermented rice due to the growth of the yeast on the surface (NICOLAU et al., 2011) [32]. Fungal growth during solid state fermentation decreases the neutral detergent fiber, acid detergent fiber, hemi-cellulosic contents of lingo-cellulosic fibers, phytic acid, polyphenols, and tannins $[33,34]$. The solid state fermentation of rice husk using Trichoderma fungi for $40 \mathrm{~d}$ significantly increased the amount of crude protein, energy and mineral content such as sodium and potassium [35]. The amount of crude protein in the fermented rice husk increased to about $97 \%$ and amount of crude fiber reduced to about $45 \%$ [36]. Two-stage solid state fermentation using Bacillus subtilis followed by Enterococcus faecium and increased the crude protein and trichloroacetic acid soluble protein(Shi et al., 2017).SSF process increased the total protein of quality protein maize flour from $9.1 \mathrm{~g} / 100 \mathrm{~g}$ to $13.4 \mathrm{~g} / 100 \mathrm{~g}$ (DM) [37].

\section{Enrichment of bioavailability and digestibility}

Phytateis an anti-nutritive component present in the cereals decreases the absorption of minerals and reduces the bioavailability due to formation of insoluble complexes of minerals (Kumar et al., 2010). Solid state fermentation decreases the amount of phytate in wholegrain cereals [38] Amount of in vitro digestibility of cereals is increased by solid state fermentation [39]. SSF improved the in vitro protein digestibility and the calculated protein efficiency ratio [31]. Fungal growth can improve protein content of substrate around $10-15 \%$ [40] and increase its digestibility (Iluyemi et al., 2006). Two-stage solid state fermentation using Bacillus subtilis followed by Enterococcus faecium effectively reduced anti-nutritional factors (soy antigenic protein, neutral detergent fiber, and phytic acid) in corn- soybean meal mixed feed (Shi et al., 2017).In vitro protein digestibility of quality protein maize flour was increased from $78.5 \%$ to $83.6 \%$ by SSF [41].

\section{Antioxidant activity enrichment}

Antioxidants prevent the oxidative damage such as cancer, atherosclerosis, diabetes, arthritis and other aging diseases in humans caused by free radicals $[42,43]$. The intake of antioxidant-containing grains reduces the oxidative damage $[44,45]$. Fermentation alters the composition of chemicals in the grains, which affect the bioactivity, antioxidant activity and digestibility [5]. By solid state fermentation process, total phenolic content of Oryza sativa and Lablab purpureus seeds $(47.53 \pm 0.20 \mathrm{GAE} \mu \mathrm{M} / \mathrm{mL})$ and flour $(46.83 \pm 0.26 \mathrm{GAE}$ $\mu \mathrm{M} / \mathrm{mL}$ )was increased from $29.48 \pm 0.20$ and $16.16 \pm 0.26$ of non fermented seeds and flour using A.awamori [2]. The TPC, antioxidant activity and antihypertensive potential of common beans was increased as 2.24, $2.45-2.73$ and 6769 times, respectively using Solid state fermentation process [46]. The total phenolic of solid state fermented common bean tempeh flour was found 2.2 fold higher than the he bean flour. Also the antiradical activity and antioxidant activity of solid state fermented common bean tempeh flour were 43 and $38 \%$, respectively [31]. Cordyceps militaris was used to produce powerful antioxidant supplement from wheat via solid state fermentation [47].The radical scavenging activity of non fermented wheat grain flour and fermented by Gf (Grifola frondosa), followed by Gg (Grifola gargal) and Gs (Grifola sordulenta) was $0.25,71.73,14.46$, and $3.02 \mathrm{mg} / \mathrm{g}$ of ascorbic acid, respectively. the $\mathrm{Fe}(\mathrm{III})$ reducing power (RP) of non fermented wheat grain flour and fermented by Gf, followed by Gg and Gs was $0.56,193.67,31.42,8.74 \mathrm{mg} / \mathrm{g}$ of ascorbic acid, respectively [48].

\section{Starch extraction}

Starch is used as raw material for preparation of many food products. It affects physico-chemical and functional properties of flour and establishes the rheological and textural properties of foods $[49,50]$. So far starch has been extracted by mechanical, hydrothermal and chemical microbiological methods. Solid state fermentation can be used to extract the starch from cereals. Microorganism used in solid state fermentation can acted as a chiral catalyst to extract starch from cereals [51]. 
Enzyme assisted starch extraction was comparatively higher than conventional extraction [52]. Chandrasekar et al. [53] employed SSF and isolated the maximum starch of $0.64 \mathrm{mg} / \mathrm{g}$ from finger millet. The enzyme solution obtained from the wheat bread by solid state fermentation using A. awamori converted nearly all of the starch into glucose and $23 \%$ of the total nitrogen (TN) into free amino nitrogen (FAN). The enzyme solution obtained from the wheat bread by solid state fermentation using A. oryzae hydrolysed 38\% of the protein and only $18.5 \%$ of the starch [54].

\section{Modification of flour}

Flour modification is the process of modifying functional properties of flour by treating grains or native flour using physical methods like extrusion, roasting and steaming; chemical methods like oxidation and esterification; and microbial methods and combination thereof [55]. Flour modification helps to eliminate undesirable physical, chemical and functional properties of native flour which in turn produces new flour with desirable functional properties. Solid state fermentation reduced the cohesive property of the cassava flour and also enhanced the elasticity of starch granules, thus prevents the easy breakdown (George, 1984). LAB fermentation enhanced the viscosity of Kefir grain flour by produced Kefiran an exopolysaccharides. The kefiran produced increase the binding ability of kefir grain flour with water and increased the interaction of flour with water in the presence of protein (Piermaria, 2008). SSF increased the swelling power and solubility of finger milletflour from 12 to 20.04 and from 17.25 to 13.25 due to change in gelatinization of properties of flour [56]. The amylase degrades the substantial amount of starch in rye flour during baking (Neumann et al., 2006) [26]. Higher dispensability, lower water solubility index and $\mathrm{pH}$ were observed in Fermented common bean (tempeh) flour than unfermented flour [31]. SSF increased the water absorption index of of QPM flour from 1.25 to $2.93 \mathrm{~g}$ gel/g dry flour) [37]

\section{Conclusion}

Currently grains are processed by various methods Increasing consumer awareness and food laws are forced adopt bio-based processes for processing and value adding of agricultural, food and biomass materials. Solid state fermentation is an environment benign, cost effective and high productive bioconversion technique. Solid state fermentation is one of the age old techniques for bio processing. The results of the previous works discussed in this review confirm that the solid state fermentation can be applied for grain processing. However adaptation of solid state fermentation at large scale production is difficult. In solid state fermentation, mixing, accumulation of heat is major problem due to solid nature of the substrates. It affects the both heat and mass transfer in the substrate. Thus it also affects the growth of microorganism and leads to poor conversion process. Therefore, after designing and developing specific bioreactors, the solid state fermentation can be applied for value addition of grains.

\section{References}

1. Senter S, Horvat R, Forbus W (1983) Comparative GLC-MS Analysis of Phenolic Acids of Selected Tree Nuts. J Food Sci 48(3): 798-799.

2. Sadh PK, Saharan P, Duhan, S, Duhan JS (2017) Bio-enrichment of phenolics and antioxidant activity of combination of Oryza sativa and Lablab purpureus fermented with GRAS filamentous fungi. Resource-Efficient Technologies.

3. Deshpande SS (1992) Food legumes in human nutrition: a personal perspective. Crit Rev Food Sci Nutr 32(4): 333-363.

4. Katina K, Liukkonen KH, Kaukovirta-Norja A, Adlercreutz H, Heinonen SM, et al. (2007) Fermentation-induced changes in the nutritional value of native or germinated rye. Journal of Cereal Science 46: 348-355.

5. Heiniö RL, Katina K, Wilhelmson A, Myllymäki O, Rajamäki T, at al. (2003) Relationship between sensory perception and flavour-active volatile compounds of germinated, sourdough fermented and native rye following the extrusion process. LWT-Food Science and Technology 36: 533-545.

6. Larroche C, Gros JB (1997) Special transformation processes using fungal spores and immobilized cells, Biotechnology of aroma compounds. Adv Biochem Eng Biotechnol 55: 179-220.

7. Gervais P, Marechal P, Molin, P (1996) Water relations of solid state fermentation. Journal of scientific \& industrial research 55: 343-357.

8. Nigam P, Singh D (1994) Solid-state (substrate) fermentation systems and their applications in biotechnology. J Basic Microbiol 34(6): 405423.

9. Pandey A, Soccol CR, Mitchell D (2000) New developments in solid state fermentation: I-bioprocesses and products. Process Biochem 35(10): 1153-1169.

10. Couto SR, Sanromán MA (2006) Application of solid-state fermentation to food industry-a review. J Food Eng 76: 291-302.

11. Gombert AK, Pinto AL, Castilho LR, Freire DM (1999) Lipase production by Penicillium restrictum in solid-state fermentation using babassu oil cake as substrate. Process Biochem 35(1-2): 85-90.

12. Joshi V, Sandhu D (1996) Preparation and evaluation of an animal feed byproduct produced by solid-state fermentation of apple pomace. Bioresour Technol 56(1/2): 251-255

13. Ghadi A, Mahjoub S, Mehravar R (2011) Management of Glucose Production Process from Rice Husk by Solid State Fermentation Method. International Conference on Biotechnology and Environmental Management (IPCBEE) Singapore.

14. Mazutti M, Ceni G, Di Luccio M, Treichel H (2007) Production of in ulinase by solid-state fermentation: effect of process parameters on production and preliminary characterization of enzyme preparations. Bioprocess Biosystems Eng 30(5): 297-304.

15. Paredes-Lopez O, Guzman-Maldonado S, Alpuche-Solis A (1998) Solid substrate fermentation: a biotechnological approach to bioconversion of wastes. Bioconversion of waste materials to industrial products. Springer 103-153.

16. Chen HZ, Xu J, Li ZH (2005) Temperature control at different bed depths in a novel solid-state fermentation system with two dynamic changes of air. Biochem Eng J 23(2): 117-122.

17. Aguilar CN, Contreras-Esquivel JC, Rodriguez R, Prado LA, Loera O (2004) Differences in fungal enzyme productivity in submerged and 
solid state cultures. Food Science and Biotechnology 13(1): 109-113.

18. Pandey A, Soccol C, Rodriguez-Leon J, Singh-Nee Nigam P (2001) "Solid State Fermentation in Biotechnology: Fundamentals and Applications" Reference Book Asiatech Publishers, Inc.

19. Gänzle MG (2014) Enzymatic and bacterial conversions during sourdough fermentation. Food Microbiol 37: 2-10.

20. Chandrasekar V, Ganapathy S, Karthikeyan S (2016b) Enhancing Alpha Amylase Activity of Finger Millet (Eluesine coracana) for Improving Baking Property through Solid State Fermentation. Advances in Life Sciences 5(10): 4069-4076.

21. Sodhi HK, Sharma K, Gupta JK, Soni SK (2005) Production of a thermostable $\alpha$-amylase from Bacillus sp. PS-7 by solid state fermentation and its synergistic use in the hydrolysis of malt starch for alcohol production. Process Biochem. 40: 525-534.

22. Dominguez A, Costas M, Longo MA, Sanromán A (2003) A novel application of solid state culture: production of lipases by Yarrowia lipolytica. Biotechnol Lett 25(15): 1225-1229.

23. Ibrahim SE, El Amin HB, Hassan EN, Sulieman AME (2012) Amylase production on solid state fermentation by Bacillus spp. Food and Public Health 2(1): 30-35.

24. Fayle SE, Gerrard JA (2002) The Maillard Reaction Royal Society of Chemistry.

25. Goesaert H, Slade L, Levine H, Delcour JA (2009) Amylases and bread firming-an integrated view. Journal of Cereal Science 50: 345-352.

26. Neumann H, Stephan H, Brümmer J (2006) Roggen als Rohstoff und Technik der Roggen sauerteigführung. Handbuch Sauerteig, Behr's Verlag, Hamurg, pp. 185-284.

27. Chancharoonpong C, Hsieh PC, Sheu SC (2012) Effect of different combinations of soybean and wheat bran on enzyme production from Aspergillus oryzae S. APCBEE Procedia 2: 68-72.

28. Romero-Gomez S, Augur C, Viniegra-González G (2000) Invertase production by Aspergillus niger in submerged and solid-state fermentation. Biotechnol Lett 22(15): 1255-1258.

29. Yanfang Z, Han G (2011) Optimization of peptidase production conditions in koji making. African Journal of Agricultural Research. 6: 4349 4356.

30. Lio J, Wang T (2012) Solid-state fermentation of soybean and corn processing co-products for potential feed improvement. J Agric Food Chem 60(31): 7702-7709.

31. Reyes-Bastidas M, Reyes-Fernández EZ, López-Cervantes J, Milán-Carrillo J, Loarca-Piña GF, et al. (2010). Physicochemical, nutritional and antioxidant properties of tempeh flour from common bean (Phaseolus vulgaris L.). Food Sci Technol Int 16(5): 427-434.

32. Nicolau A, Georgescu L, Bolocan A (2011) Impact of bio-processing on rice. The Annals of the University Dunarea de Jos of Galati, Fascicle VIFood Technology 35(1): 19-26.

33. Elyas SH, El Tinay AH, Yousif NE, Elsheikh EA (2002) Effect of natural fermentation on nutritive value and in vitro protein digestibility of pearl millet. Food Chem 78: 75-79.

34. Manmdebvu P, West J, Froetschel M, Hatfield R, Gates R, et al. (1999) Effects of enzyme and microbial treatment of Bermuda grass forages before ensiling on cell wall composition, end products of silage fermentation and in situ digestion kinetics. Anim Feed Sci Technol 77: 317-329.

35. Aderolu A, Iyayp E, Onilude A (2007) Changes in nutritional value of rice husk during Trichoderma viride degradation. Bulgarian Journal of Agricultural Science 13: 583.
36. Zaid AA, Ganiyat O (2009) Comparative utilization of biodegraded and undegraded rice husk in Clarias gariepinus diet. African journal of Biotechnology 8(7).

37. Cuevas-Rodríguez EO, Milán-Carrillo J, Mora-Escobedo R, Cárdenas-Valenzuela OG, Reyes-Moreno C (2004) Quality protein maize (Zea mays L.) tempeh flour through solid state fermentation process. LWT Food Science and Technology 37: 59-67.

38. Liukkonen KH, Katina K, Wilhelmsson A, Myllymäki O, Lampi AM, et al. (2003) Process-induced changes on bioactive compounds in whole grain rye. Proc Nutr Soc 62(1): 117-122.

39. Zadražil F, Galletti G, Piccaglia R, Chiavari G, Francioso O (1991) Influence of oxygen and carbon dioxide on cell wall degradation by whiterot fungi. Anim Feed Sci Technol 32: 137-142.

40. Shojaosadati SA, Babaeipour V (2002) Citric acid production from apple pomace in multi-layer packed bed solid-state bioreactor. Process Biochemistry 37(8): 909-914

41. Reyes-Moreno C, Cuevas-Rodríguez EO, Milán-Carrillo J, Cárdenas-Valenzuela OG, Barrón-Hoyos J (2004) Solid state fermentation process for producing chickpea (Cicer arietinum L) tempeh flour. Physicochemical and nutritional characteristics of the product. J Sci Food Agric 84: 271-278.

42. Halliwell B, Gutteridge JM (1985) Free radicals in biology and medicine. Pergamon.

43. Hollman PCH (2001) Evidence for health benefits of plant phenols: local or systemic effects? J Sci Food Agric 81: 842-852.

44. Jenkins DJ, Kendall CW, Jackson CJ, Connelly PW, Parker T, et al. 2002. Effects of high-and low-isoflavone soyfoods on blood lipids, oxidized LDL, homocysteine, and blood pressure in hyperlipidemic men and women. Am J Clin Nutr 76(2): 365-372.

45. Watanabe S, Yamaguchi M, Sobue T, Takahashi T, Miura T, et al. (1998) Pharmacokinetics of soybean isoflavones in plasma, urine and feces of men after ingestion of $60 \mathrm{~g}$ baked soybean powder (kinako). J Nutr 128(10): 1710-1715.

46. Guzmán-Uriarte ML, Sánchez-Magaña LM, Angulo-Meza GY, Cuevas-Rodríguez EO, Gutiérrez-Dorado R, et al. (2013) Solid state bioconversion for producing common bean (Phaseolus vulgaris L.) functional flour with high antioxidant activity and antihypertensive potential. Food and Nutrition Sciences 4: 480.

47. Zhang Z, Lv G, Pan H, Fan L, Soccol CR, et al. (2012) Production of powerful antioxidant supplements via solid-state fermentation of wheat (Triticum aestivum Linn.) by Cordyceps militaris. Food Technol Biotechnol 50(1): 32-39.

48. Postemsky P, Curvetto N (2014) Enhancement of wheat grain antioxidant activity by solid state fermentation with Grifola spp. J Med Food. 17(5): 543-549.

49. Adebowale K, Afolabi T, Olu-Owolabi B (2005) Hydrothermal treatments of Finger millet (Eleusine coracana) starch. Food Hydrocolloids 19: $974-983$.

50. Balasubramanian S, Sharma R, Kaur J, Bhardwaj N (2011) Isolation, Modification and Characterization of Finger Millet (Eleusine coracana) Starch. Journal of Food Science and Engineering 1: 339.

51. Stanbury PF, Whitaker A, Hall SJ (2013) Principles of fermentation technology. Elsevier.

52. Zheng GH, Bhatty R (1998) Enzyme-assisted wet separation of starch from other seed components of hull-less barley. Cereal Chemistry 75(2): 247-250. 
53. Chandrasekar V, Ganapathy S, Thirupathi V (2016) Response Surface Methodology Optimization of Starch Isolation from Finger Millet (Eleusine coracana) through Solid State Fermentation. Madras Agricultural Journal 103: 96-101.

54. Wang R, Godoy LC, Shaarani SM, Melikoglu M, Koutinas A, et al. (2009) Improving wheat flour hydrolysis by an enzyme mixture from solid state fungal fermentation. Enzyme Microb Technol 44: 223-228.

55. Tharanathan RN (2005) Starch-value addition by modification. Crit Rev Food Sci Nutr 45(5): 371-384

This work is licensed under Creative Commons Attribution 4.0 License

DOI: $10.19080 /$ NFSIJ.2017.03.555619
56. Chandrasekar V, Thirupathi V, Ganapathy S (2016a). Effect of Solid State Fermentation on Swelling Power and Solubility of Finger Millet (Eleusine coracana). Advances in Life Sciences 5(4): 1356-1365.

57. Shi C, Zhang Y, Lu Z, Wang Y (2017) Solid-state fermentation of corn-soybean meal mixed feed with Bacillus subtilis and Enterococcus faecium for degrading anti-nutritional factors and enhancing nutritional value. J Anim Sci Biotechnol 8: 50.

\section{Your next submission with Juniper Publishers will reach you the below assets}

- Quality Editorial service

- Swift Peer Review

- Reprints availability

- E-prints Service

- Manuscript Podcast for convenient understanding

- Global attainment for your research

- Manuscript accessibility in different formats

(Pdf, E-pub, Full Text, Audio)

- Unceasing customer service

Track the below URL for one-step submission https://juniperpublishers.com/online-submission.php 